\title{
SCOTLAND'S INDEPENDENCE MOVEMENTS - THE MAIN CHALLENGES IN THE ECONOMIC SPHERE IN THE ASPECT OF POTENTIAL SEPARATION OF SCOTLAND FROM THE UNITED KINGDOM
}

\author{
Ewa Radomska, PhD, Assistant Professor \\ Pedagogical University of Cracow, Poland \\ Faculty of Political Sciences, Institute of Law \\ ewa.rad@poczta.fm
}

\begin{abstract}
The purpose of the article is to analyze the process of Scotland's independence movements and to identify the main challenges in the economic sphere in the aspect of potential separation of Scotland from United Kingdom. As a basis for the research method a study based on the analysis of selected information sources was used. The attempts by Scotland to separation from the Great Britain, taken over the centuries, ended in failure, but have contributed to increase of Scottish autonomy. The results of the referendum on the United Kingdom's continuing membership of the European Union have become the impulse for intensification of Scottish activity towards secession from the Great Britain. Scotland wants to decide independently on its own economic development based mainly on oil and natural gas as well as renewable energy sources. The EU membership would enable Scotland to attain the goals set up by Scottish government. The benefits of being a member of the EU, such as access to the Single European Market, structural funds, ect., Scotland may lose if it stays within the United Kingdom. The government in London is fully committed to maintaining the unity of the United Kingdom and blocks Scottish activities aimed at independence. Further scenario will depend on the results of the future directions, forms and principles for further co-operation between the United Kingdom and the European Union.
\end{abstract}

Keywords: Scotland, independence, autonomy, United Kingdom, Great Britain, European Union, economy

\section{INTRODUCTION}

Scotland covers the northern part of the island of Great Britain and the Hebrides, Orkney and Shetland and is a part of the United Kingdom, along with England, Wales and Northern Ireland. According to National Records of Scotland, Scotland has a population of 5,373,000 residents. ${ }^{1}$ In the European Union membership referendum on June 23, 2016, the majority (51.9 per cent) of the British voted in

National Records of Scotland. 2016. [http://www.nrscotland.gov.uk/] Accessed 15.11.2018 
favour of leaving the European Union, which was primarily decided by the voters from England. 62 per cent of Scots with a turnout of 67.2 per cent supported the UK's remain in the EU, 38 per cent of them were against. ${ }^{2}$ Over the years, Scotland has gained more and more autonomy within the United Kingdom. However, many decisions are still in the hands of the British government, which - according to the Scots - restricts the development of Scotland. The results of the referendum have become an important impulse for the intensification of Scotland's actions in favour of secession. The Scottish government has announced that it will do everything to prevent Scotland from leaving the EU and is seeking to repeat the 2014 Scottish independence referendum counting on its positive outcome. The actions of Scotland and Northern Ireland seeking their independence are a threat to maintaining the unity of the United Kingdom. The situation is complex because several processes overlap at the same time. Finding the solution needs time. Moreover, it is difficult to disagree with the opinion of specialists, commentators and observers that various scenarios are possible.

In the article the author tries to answer the main questions: What are the main reasons for Scotland's withdrawal from the United Kingdom and how have they changed over the years? What pillars does Scotland base its economic development on and what are the main economic challenges facing Scotland in terms of potential exit from the United Kingdom? Are current conditions conducive to the Scots' aspirations for independence and accession to the EU? The questions are deliberately generic in order to highlight the most important issues in the complexity and multidimensionality of the issues.

The analysis is based on a review of available publications, including government documents, speeches by Scottish and English politicians, the results of research and analyses, the reports from various institutions and research centres, including UCL European Institute, Centre for European Policy Studies, Centre for Policy Studies, Frankfurt School - UNEP Collaborating Centre for Climate \& Sustainable Energy Finance, Bloomberg New Energy Finance. In the conditions of the process of Great Britain leaving the European Union, the issue raised in the article is the starting point for conducting further in-depth analyses taking into account the economic aspect of the potential secession of Scotland from the United Kingdom.

The structure of the article: the first part presents the current actions of Scotland in order to become independent from Great Britain. Hence, the historical context

2 Jamieson, A., Scotland Seeks Independence Again After U.K. 'Brexit' Vote, NBC News, 24 June 2016. http://www.nbcnews.com/storyline/brexit-referendum/scotland-could-seek-independence-again-after-u-k-brexit-vote-n598166] Accessed 17.11.2018 
is essential to understand grounds of these actions. In the second part, the main challenges for Scotland in the economic sphere are identified in the case of the possible separation from the United Kingdom. For Scotland, economic issues are the basis of its efforts on the way to independence. They have already been the subject of analysis before the 2014 Scottish independence referendum, but located in a different time and context than at present.

\section{SCOTLAND IN THE UNITED KINGDOM. ACTIONS TO BECOME INDEPENDENT FROM GREAT BRITAIN}

The Kingdom of England and the Kingdom of Scotland as separate states have been united since 1603 by a personal union. They became one organism on May $1,1707 .{ }^{3}$ The Treaty of Union, ratified by the parliaments of both countries, de facto complemented the personal union. It brought to life the United Kingdom of Great Britain, which also incorporated Wales. ${ }^{4}$ In 1800, the next Acts of Union were signed. On its basis, Ireland joined England, Wales and Scotland. In this way the United Kingdom of Great Britain and Ireland was established. The next important historical moment was the signing of the Anglo-Irish Treaty on December 6, 1921 by representatives of the British State and the Irish Republic, which existed in the years 1919-1922. It enabled the creation of the Irish Free State, which remained in a personal union with the United Kingdom as its dominion. This caused gaining independence from the English authorities. On December 6, 1922, after the entry into force of the treaty, Northern Ireland separated from the Irish Free State (later in 1937, the name of the state was changed to Ireland, and in 1949 Ireland was transformed into a republic) and reunited with Great Britain. In 1927 the United Kingdom has changed its name for the third time, this time to become the United Kingdom of Great Britain and Northern Ireland.

Since the establishment of the United Kingdom, the Scots have tried several times to become independent from Great Britain. The particularly violent actions were taken in the eighteenth century. The most significant of them was the so-called the Forty-Five Rebellion in $1745 .{ }^{5}$ After suppressing the uprising, the British introduced repressions. They forbid, among others, clan system, weapon possession, the use of national dress and Gaelic language. At the end of the nineteenth century, there was a shift to the idea of Scottish autonomy, proposed in 1885 by William Gladstone, which would grant Scotland its own government. He had the

Colley, L., Britons: Forging the Nation, 1707-1837, New Haven, Yale, 1992, p. 11

Bogdanor, V., Devolution in the United Kingdom, Oxford, 1999, p. 7

Ichijo, A., Scottish Nationalism and the Idea of Europe: Concepts of Europe and the Nation, New York, 2004 , p. 33 
support of the Liberal Party. ${ }^{6}$ However, it brought no changes. Nationalism grew during the Great Depression, when Scottish mines and smelters were declining, and the prohibition in the USA affected Scottish whisky producers. In 1934, the Scottish National Party (SNP) was formed from the merger of two parties: the National Party of Scotland, which aimed at winning independence for Scotland, and of the Scottish Party calling for greater Scottish autonomy within the United Kingdom. ${ }^{7}$ In the 1960s, when oil and gas deposits in the North Sea were discovered, the Scottish National Party intensified its activities. The actions were not in favour of increasing Scotland's autonomy and giving it more rights, but for the independence: to become independent from Great Britain. On the political scene, the party came into existence in 1970, when its candidate Winnie Ewing won a seat in the supplementary election to the House of Commons. In 1974, the party's support was already 30 per cent. Its members won 11 seats in the House of Commons. ${ }^{8}$ After the Second World War, the basis of the Anglo-Scottish consensus was to build a "welfare state" and the idea of state ownership of the industry. The period from the mid-1940s to the mid-1970s was for the union of Scotland with England "the silence before the storm", and this storm was the rule of Prime Minister Margaret Thatcher (1979-1990), when the support of the Scots for conservatives fell significantly. ${ }^{9}$ Scotland has been perceived for years as a bastion of the left. Opinions are commonly expressed there that the economic policy of the next British conservative offices, especially Thatcher, led to the dismantling of a significant part of the local industry, contributed to the occurrence of many negative social and economic effects. The reluctance for conservatives deepened during the administration of Prime Minister John Major (1990-1997). According to Craig McAngus, a lecturer in political science at the University of Aberdeen, the existing differences in the approach of Scotland and England to economic issues have become an important impulse for the independence of Scotland. ${ }^{10}$ The Scots advocating secession from the United Kingdom readily refer to the example of the Republic of Ireland. In 1921, then the Free Republic of Ireland became independent from the British authorities. Although contemporary conditions are

$6 \quad$ McCrone, D., Understanding the Nation: The Scottish Question, w: The Fate of the Nation-State, Montreal, 2004, p. 217

7 Hanham, H.J., Scottish Nationalism, London, 1969, p. 163

8 Duerr, G., Scottish Secession: Prospects for Independence after Blair?, paper presented at the conference Britain after Blair, The Legacy and the Future, The Gleacher Center, University of Chicago Business School, Chicago, 29 August 2007

9 Troitino, D.R., Margaret Thatcher and the EU, Proceedings for the Institute for European Studies, No. 6, 2009, pp. 124-150

10 McAngus, C., Scottish independence back in play after Brexit shock - with a note of caution, The Conversation, 24 June 2016. [http://theconversation.com/scottish-independence-back-in-play-after-brexitshock-with-a-note-of-caution-61457] Accessed 05.12.2018 
different, this comparison is reiterated, considering that the small Republic of Ireland, a member state of the European Union, is doing very well as an independent state. David McCrone draws attention to the similarities between the Republic of Ireland and Scotland: a similar "Celtic" history, a similar number of inhabitants, experience in being "under the control" of Westminster. ${ }^{11}$ On the basis of the conducted research, he assessed that the Scots feature in "mature nationalism" in the sense of a strong sense of identity. "Being a Scot" is more important than "being British.”

\subsection{The 1997 Independence Referendum - greater autonomy}

Although the postulate to restore the Scottish parliament in the context of increasing autonomy appeared already in the second half of the nineteenth century and considered to be reactivated before World War I, its establishment became possible only in the 1990s. during the administration of Tony Blair (1997-2007). Decentralisation was one of the points of the Labour Party program. The Scots, using the change of English policy, in 1997 held a referendum in which 74 per cent voters supported Scotland's own parliament. ${ }^{12}$ As a result, the British parliament passed a constitutional law, the Scotland Act, which granted Scotland autonomy. The Scottish parliament has been in operation since 1999. It has gained the power to make decisions on economy, education, health care, agriculture and environmental protection. Foreign policy and defence policy remained under the control of London. With time, the critical voices of England's residents appeared in relation to subsidies from the central budget for Scotland of about $£ 6$ billion, funding higher education for young Scots, free bus tickets for pensioners and bedridden, elderly citizens (such privileges were not enjoyed by the people of England). Another dislike was the presence of Scottish MPs in the House of Commons that had influence on the resolution of health and education issues in England, in a situation where English MPs had no right to regulate these areas in Scotland. According to former British Prime Minister, John Major, the consent for Scotland's autonomy and its own parliament became a "Trojan horse" in Scotland's quest for independence. ${ }^{13}$ The actions for the independence continued, while in England anxiety was growing. The Scottish National Party continued its efforts for winning independence in the conditions of increased support for the people of Scotland in favour of leaving the United Kingdom. In a survey by the YouGov research company from September 2006, 44 per cent of Scots were in favour of independence,

McCrone, op. cit., note 6, p. 215

12 Robbins, K., Britain and Europe: Devolution and Foreign Policy, International Affairs, Vol. 74, No. 1, 1998, pp. $105-118$

13 Major, J., John Major: the Autobiography, New York, 1999 
and 42 per cent for remaining in the United Kingdom. This was not a result that would guarantee the success of the independence referendum, but it became an important signal that the Scots do not exclude such an option. ${ }^{14}$

\subsection{Scottish independence referendum}

The project of the bill on the independence referendum was presented in 2007 by the First Minister of Scotland and the leader of the Scottish National Party, Alex Salmond. It was not until four years later that the Scottish National Party obtained most of the seats (69 out of 129) in the Scottish Parliament, which allowed it to return to the idea of announcing a referendum. At the beginning of 2012, the Scottish Government and the British Government began consultations regarding the referendum. The information was also given that the referendum would take place in autumn 2014, and the question will be: "Should Scotland be an independent country?" On October 15, 2012, the Prime Ministers of Scotland and the UK signed the so-called Edinburgh Agreement ${ }^{15}$ allowing the Scottish government to hold a referendum. A year later, the Bill for the Scottish Independence Referendum Act 2013 was approved by the Scottish Parliament, which was treated as an exception (constitutional matters are the responsibility of Westminster), and granted the so-called Royal Assent. ${ }^{16}$ Formally, the road to the campaign and the referendum was opened. In November 2013, the Scottish government published a study on Scotland's future after independence, "Scotland's Future. The Guide to an Independent Scotland "17. Its records are still valid. It draws attention to the potential benefits of replacing the union within the United Kingdom by intensifying economic cooperation with the Scandinavian countries, the Baltic republics and the countries of Central and Eastern Europe. Scotland also perceives its strength in membership in the European Union, access to the Single European Market and its freedoms (movement of goods, services, capital and labour) and the EU regional policy instruments. Drawing on the smaller EU states, Slovenia, Denmark, the Republic of Ireland and Estonia, Scotland wants to develop through the cooperation with other members of the Community. The economic policy is to be based primarily on oil and gas deposits. They would form the basis of the energy cooperation network with Scandinavia, while at the same time con-

\footnotetext{
14 Duerr, op. cit., note 8, p. 3

15 Agreement between the United Kingdom Government and the Scottish Government on a referendum on independence of Scotland, Edinburgh, 15 October 2012

16 McInnes, R.; Ayres, S.; Hawkins, O., Scottish Independence Referendum 2014. Analysis of results, House of Commons, Research Paper Vol.50, No. 50, 2014, p. 22

17 Scotland's Future. The Guide to an Independent Scotland, Scottish Government, Edinburgh, November 2013. [http://www.gov.scot/resource/0043/00439021pdf] Accessed 17.12.2018
} 
tinuing the cooperation in this respect with other parts of Great Britain, but on other conditions than up to this time. For many years, the advocates of Scottish independence criticised London for inefficient spending of taxes paid by companies extracting oil and gas from the North Sea. It was postulated that these funds should be invested in a special fund for future generations in improving the quality of public services. The Scottish Government also counts on taking over all UK assets located in Scotland. It is mainly about armed forces, or base of submarines in Faslane, Scottish air forces with bases in Lossiemouth and Kinloss, and Royal Regiment of Scotland, whose battalions would form the core of the army of the independent country. The Scottish government has promised that after gaining the independence, it will begin its efforts to grant Scotland a membership in the European Union. ${ }^{18}$

The campaign before the 2014 referendum focused on the threat of deterioration in the quality of public services (primarily health care) in Scotland under the rule of Tories. Salmond sensed the fears of most of his countrymen. The supporters of independent Scotland said that if they won the referendum, their country would be richer thanks to oil and gas deposits in the North Sea. According to the opponents of the secession, Scotland - if gained the independence - would economically decline, foreign capital would withdraw from it, and the recession would occur. They accused the separatists of basing taxes on oil and gas revenues which will eventually shrink because the deposits were running out and prices were falling. It is not possible to build welfare states on decreasing resources - they assessed. The pre-referendum campaign was focused on reducing fears and highlighting the benefits associated with the secession. It was more of a wishful nature than supported by multilateral, reliable analyses taking into account different scenarios. In the last period of its duration, the predominance of opponents of the secession who use the slogan "Better Together" decreased. Therefore, the British government has promised to extend Scottish autonomy within a common state, so that the Scots would want to stay in it. The Unionists hoped that this would allow the scenario of the 1995 Quebec referendum to be repeated, ${ }^{19}$ granting greater autonomy to the province, formulated at the last minute, contributed to the rejection of secession. This is also the case in Scotland.

The referendum was held on September 18, 2014 during the administration of Prime Minister David Cameron (2010-2016). What were the results? "No" to independence, "yes" to wider changes and greater autonomy. Nearly 84.6 per cent

\footnotetext{
18 ibid.

19 Lynch, P., Scottish Independence, the Quebec Model of Secession and the Political Future of the Scottish National Party, Nationalism and Ethnic Politics, Vol. 11, No. 4, 2005, pp. 503-531
} 
of Scots took part in the referendum. In many districts, the turnout reached 90 per cent. 55.3 per cent of the voters (2, 001,926 votes cast) was against the independence of Scotland. They feared that without England, Scotland could not handle. At that time, many of them assessed that Scotland was too weak to create its own state, that the European Union might not accept it, while the membership in this group is very important for pro-European Scots. The support of the secession by 44.7 per cent. of Scots $(1,617,989$ votes cast) were not enough for Scotland to separate from the United Kingdom. ${ }^{20}$ As the commentators pointed out, the results of the referendum ensured Great Britain, at least the temporary, the maintenance of the United Kingdom. The Scottish decision also gave Great Britain a chance to avoid financial instability foreseen by some experts in the case of secession in Scotland and to maintain the strength of British voice in international organisations.

\subsection{The United Kingdom European Union membership referendum}

A speech by Prime Minister David Cameron on January 23, 2013 in London ${ }^{21}$ focusing on the need to reform the European Union, was also a programmatic speech of the leader of the Conservative Party seeking to maintain his leadership among conservatives and to win supporters before the parliamentary elections in Great Britain. In the Conservative Party, a strong faction of opponents of Great Britain's membership in the European Union was strengthening. Euroscepticism was growing in the conservative electorate. The independence aspirations of the Scottish separatists became clear. In such complex conditions, the speech brought success to Cameron, ensuring in 2015 the renewal of the mandate of the Prime Minister. ${ }^{22}$ The postulate of renewing the legitimacy of the government to continue UK participation in the process of European integration through a national referendum is in line with the principles of democracy. However, it is hard not to notice that Cameron treated the EU Referendum in terms of the bargaining chip in negotiations on the United Kingdom 's participation in the Union "on its terms." It was a risky operation. Michael Emerson from the Centre for European Policy Studies (CEPS) called the Prime Minister's actions: "a game of Russian

McInnes at al., op. cit., note 16, p. 1

21 David Cameron's EU speech, 23 January 2013. [http://www.theguardian.com/politics/2013/jan/23/ david-cameron-eu-speech-referendum] Accessed 28.12.2018

22 Erlanger, S.; Castle, S., David Cameron and Conservatives Get Majority in British Election, The New York Times, 8 May 2015. [http://www.nytimes.com/2015/05/09/world/europe/david-cameron-and-conservatives-emerge-victorious-in-british-election.html] Accessed 06.01.2019 
roulette". ${ }^{23}$ As a result of the referendum of June 23, 2016, the supporters of leaving the European Union by the United Kingdom won. Brexit became a fact.

\subsection{Scottish reaction to the referendum results}

Following the announcement of the referendum results, the First Scottish Minister and the Scottish National Party chairman, Alex Salmond, resigned, followed by Nicola Sturgeon, the advocate of Scottish independence and Scotland's membership in the European Union. She attended the inaugural session of the parliament with a speech in which she emphasised that Scotland outside the European Union is democratically unacceptable, and that the integration does good to Scotland. She returned to the idea of announcing the second independence referendum. The polls for the local media carried out after the referendum on Brexit show that 54 per cent (according to the "Daily Record" from Glasgow) and 59 per cent ("Sunday Post" from Dundee) of the Scots would vote for the independence. According to the observers, the referendum would make sense if at least 60 per cent of the Scots voted in polls for the independence. ${ }^{24}$ The Scottish Parliament supported the initiation by Sturgeon direct talks on the future of Scotland both with the European Commission and with the government in London. On June 26, 2016, the First Minister of Scotland spoke in Brussels with the Presidents of the European Commission and the European Parliament on the future place of Scotland in the EU. ${ }^{25}$ They both expressed their readiness to listen to Scotland, making it clear that the arrangements must first be made between the government in Scotland and the government in London. According to prof. Michaela Keating from the University of Aberdeen, it can be expected that the current EU member states, including Spain, will block Scotland's accession to the European Union. ${ }^{26}$ The Spanish government fears that the "Scottish route" may be followed by Catalonia or Basque, which would endanger the unity of Spain. The facts are the independence tendencies in Europe are growing. ${ }^{27}$ In July 2016, Sturgeon announced that

23 Emerson, M., Cameron's 'renegotiations' (or Russian roulette) with the EU. An interim assessment, CEPS - Centre for European Policy Studies Working Documents, No. 413, 2015, p. 1

24 McAngus, op. cit., note 10

25 Rankin, J.; Carrell, S.; Oltermann, Ph., Nicola Sturgeon's plea to EU leaders meets with sympathy but little hope, The Guardian, 29 June 2016. [http://www.theguardian.com/politics/2016/jun/29/nicolasturgeon-scotland-plea-eu-leaders-sympathy-little-hope] Accessed 08.01.2019

26 Keating, M., Brexit Reflections - How could Scotland remain in the EU?, Centre on Constitutional Change, University of Edinburgh, Edinburgh, 8 July 2016. [http://www.centreonconstitutionalchange.ac.uk/blog/brexit-reflections-how-could-scotland-remain-eu] Accessed 21.01.2019

27 Colomb, C.; Bakke, K.; Tomaney, J., Shaping the territory in Scotland, Catalonia and Flanders. Analysing contemporary debates on devolution and independence from a spatial planning and territorial cohesion lens, UCL European Institute, Working Paper, No. 5, 2014, pp. 1-12 
she was planning to start preparations for the next referendum. ${ }^{28}$ In March 2017, the Scottish Government's proposal to organise a second independence referendum was supported by the majority of deputies representing the Scottish National Party and the Green Party, thus giving the Scottish First Minister Nicola Sturgeon a mandate to start negotiations on the preparation of the referendum (it requires the consent of the government in London).

\subsection{The reaction of England to the activities of Scotland for its independence}

After the United Kingdom European Union membership referendum, before his resignation as Prime Minister, David Cameron urged the British Parliament to maintain the unity of the United Kingdom. ${ }^{29}$ On July 2, 2016, at a session opening the next term of Holyrood - the Scottish parliament, the British Queen Elizabeth II did not raise the issue of the referendum and its results. She spoke about "stay calm and collected" when the events take on "remarkable speed". ${ }^{30}$ The Queen's words were read as an appeal to rethink the need to repeat the referendum on the independence of Scotland. Before the 2014 referendum, experts and British politicians, including the president of the Bank of England and the Prime Minister, warned that the case of Scotland leaving the UK would have negative economic consequences. Already in 2012, Cameron during the visit to Edinburgh argued that the United Kingdom should last uninterruptedly, as both England and Scotland only jointly are able to maintain a strong position in the international arena. He assessed then that independent Scotland would not be as strong, secure, rich and just as it is today as part of the United Kingdom. The secession of Scotland would cause Great Britain to lose one third of its territory, resulting in marginalisation in NATO and the UN Security Council, because it counts as one of the most important countries in Europe only in the union with Scotland. ${ }^{31}$ Although the Prime Minister did not mention it, the fact that Great Britain is the largest producer of crude oil and gas in the European Union is also important. Most of this production comes from the areas that can be taken over by independent Scotland. According to Scottish politicians, since Britain is afraid of undermining

28 Cramb, A., Nicola Sturgeon: Scottish referendum could be held next year, The Telegraph, 17 July 2016. [http://www.telegraph.co.uk/news/2016/07/17/sturgeon-scottish-referendum-could-be-held-nextyear/] Accessed 23.01.2019

29 PM Commons statement on the result of the EU referendum, 27 June 2016. [https://www.gov.uk/government/speeches/pm-commons-statement-on-the-result-of-the-eu-referendum-27-june-2016] Accessed 25.01.2019

30 The Queen's address to the Scottish Parliament, 2 July 2016. [https://www.royal.uk/queens-address-scottish-parliament-2nd-july-2016] Accessed 30.01.2019

31 PM Scotland speech, 16 February 2012. [https://www.gov.uk/government/speeches/transcript-pmscotland-speech] Accessed 01.02.2019 
the stability of its economy after Scotland has become independent, it means that England needs Scottish economy more than Scotland - British economy. Prime Minister Theresa May stated in March 2017 that she would not agree to repeat the Scottish independence referendum as long as the negotiations with the EU on Brexit last. The negotiating period began on 29 March 2017, when the United Kingdom served the withdrawal notice under Article 50 of the Treaty on European Union; under the two-year deadline, the period was originally to end on 29 March 2019. Negotiations on the withdrawal agreement (which includes a transitional period and an outline of the objectives for a future relationship between the UK and the EU) were concluded in November 2018, with the European Union indicating that no further negotiation or changes before the UK legally leaves will be possible. The UK and leaders of the 27 other EU countries have agreed to delay Brexit moving the deadline from 29 March to 31 October 2019. The official objective is to allow time for the withdrawal agreement to be ratified. The divorce deal struck by the EU and the British government has repeatedly been rejected by the UK parliament. ${ }^{32}$ Scotland's First Minister, Nicola Sturgeon has said on 21 April 2019, that she would back to the idea of the next independence referendum (on May 2021): "Independence would allow us to protect our place in Europe. It would enable us to nurture our most important relationships - those with the other countries of the British Isles - on the basis of equality. And it would mean that decisions against our will and contrary to our interests cannot be imposed on us by Westminster. It would put our future into our own hands - with the decisions that shape our future and determine our relationship with other countries taken here in our own parliament. That is the essence of independence (...) If Scotland is taken out of the EU, the option of a referendum on independence within that timescale must be open to us". ${ }^{33}$ T. May has rejected any discussion on the new Scottish independence referendum plans. Repeated opinion polls show a narrow majority of Scottish people are against independence, with only a minority backing a referendum in the next two years. Others show a majority of Scottish voters would support a referendum over the next decade. N. Sturgeon appeared to acknowledge there was not yet a majority in favour of leaving the UK and said she wanted to build a consensus with opposition parties on Scotland's constitutional and political future. ${ }^{34}$

32 Brexit: UK and EU agree delay to 31 October, BBC, 11 April 2019. [https://www.bbc.com/news/ uk-politics-47889404] Accessed 02.05.2019

33 Brexit and Scotland's future: First Minister statement, 24 April 2019. [https://www.gov.scot/publications/first-minister-statement-brexit-scotlands-future/] Accessed 03.05.2019

34 Carrell, S., Sturgeon outlines new Scottish independence referendum plans, The Guardian, 24 April 2019. [https://www.theguardian.com/politics/2019/apr/24/sturgeon-outlines-new-scottish-independence-referendum-plans] Accessed 03.05.2019 


\section{THE MAIN CHALLENGES FOR SCOTLAND IN THE ECONOMIC SPHERE IN TERMS OF THE POSSIBLE SEPARATION OF SCOTLAND FROM THE UNITED KINGDOM}

Leaving the European Union (EU) represents the greatest change to the UK and Scottish economies. The Fraser of Allander Institute has set out the long term economic implications of Brexit on Scottish Economy. ${ }^{35}$ Its analysis describes how trade opens businesses to new opportunities for exporting and investment and how labour mobility boosts labour supply, helping to increase productivity and address demographic challenges in countries, with an ageing population. Competition helps efficiency, product specialisation and growth and financial integration deepens and broadens capital markets. All these are expected to be impacted in one way or another by becoming less integrated with the EU. Three scenarios for the future relationship with the EU post-Brexit are modelled: a Norway model, a Switzerland model and a WTO model. All these scenarios show significant negative impacts of Brexit on the Scottish economy (Table 1).

Table 1. Impact of Post-Brexit Scenarios on Scottish Economy after 10 years

\begin{tabular}{|l|l|l|l|}
\hline & Norway model & Switzerland model & WTO model \\
\hline Exports of Goods & $-12 \%$ to $-18 \%$ & $-12 \%$ to $-18 \%$ & $-26 \%$ \\
\hline Exports of Services & $-11 \%$ to $-18 \%$ & $-18 \%$ to $-22 \%$ & $-25 \%$ \\
\hline GDP $(\%)$ & $2-3 \%$ lower & $3-4 \%$ lower & $5 \%$ lower \\
\hline GDP $£$ compared to $2015-16$ & $£ 3-5$ bn lower & $£ 4-6$ bn lower & $£ 8$ bn lower \\
\hline Real wages $(\%)$ & $3-4 \%$ lower & $5-6 \%$ lower & $7 \%$ lower \\
\hline Real wages $(£$ full-time earnings) & $£ 800-1,200$ lower & $£ 1,200-1,600$ lower & $£ 2,000$ lower \\
\hline Employment level & $1-2 \%$ reduction & $1-2 \%$ reduction & $3 \%$ reduction \\
\hline Numbers of jobs & 30,000 jobs lost & 30,000 jobs lost & 80,000 jobs lost \\
\hline
\end{tabular}

Source: Fraser of Allander Institute, Long-term Economic Implications of Brexit, October 2016.

Scottish Government analysis ("Scotland's Place in Europe: People, Jobs and Investment") show, that Brexit will significantly weaken Scottish economy and result in slower economic growth and lower incomes than otherwise, but also that a UK outside the European Single Market and Customs Union will have the most damaging consequences for Scotland. ${ }^{36}$

Scotland's aspirations for the independence, despite being blocked by the British government, have been particularly strong in recent years. The Scottish authorities are aware that with the possible independence, there is a thorough reconstruction

\footnotetext{
35 Fraser of Allander Institute, Long-term Economic Implications of Brexit, October 2016

36 Scotland's Place in Europe: People Jobs and Investment. Summary, Scottish Government, January 2018, p.3
} 
of the state's structures and policy. Scotland strives to become independent from the United Kingdom in the economic sphere and decide independently on the directions of economic development. This does not mean suspending the cooperation, but diversifying it and placing a greater emphasis on cooperation within the European Union. The next part of the article highlights the main challenges facing Scotland in terms of possible detachment from the United Kingdom. The issues raised in this part of the article do not exhaust the subject, they include selected aspects (relating to trade, currency, energy industry and renewable energy sector, financial sector) and require further in-depth analyses and research.

The development of foreign trade affects the economy in many ways. It brings benefits in terms of specialisation and increasing the scale of production, entails an increase in investment (increasing export production requires additional capital accumulation), enables the transfer of new technologies and knowledge to the country (in the case of countries with a lower degree of technological advancement, it contributes to productivity growth and acceleration of economic development). The freedom to trade goods and services across the UK supports greater productivity through knowledge sharing, specialisation and economies of scale. Majority of Scottish exports are directed to England and other parts of Great Britain (Wales and Northern Ireland). ${ }^{37}$

Figure 1. Scotland's Exports (excluding oil and gas) to the Rest of the UK, EU and Non-EU, 2002-2017

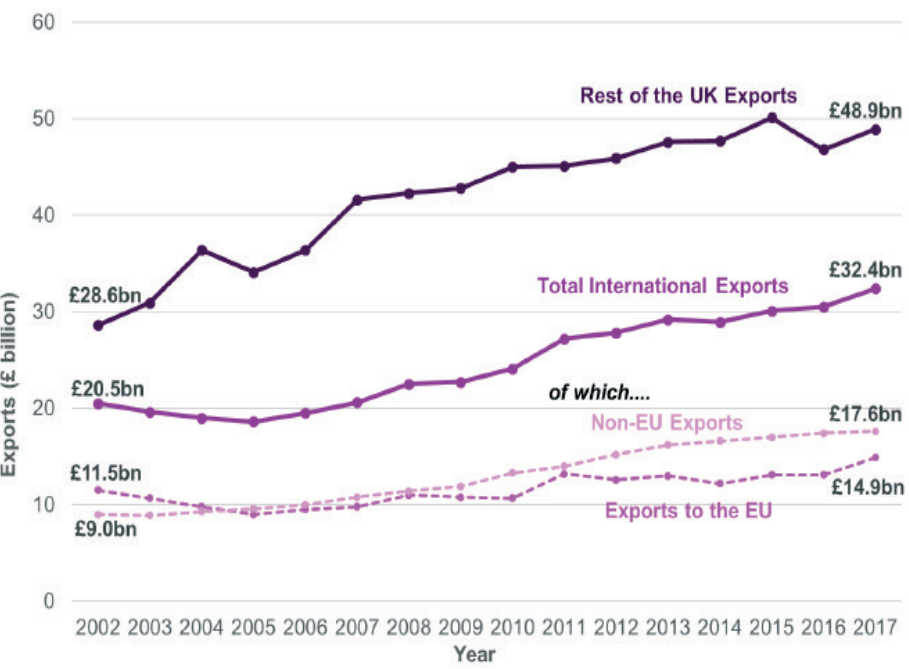

Source: Export Statistics Scotland 2019.

37 Mahoney, D.; Knox, T., Scotland: Could it become Greece without the sun?, Centre for Policy Studies, Economic Bulletin, No. 80, 2016, p. 4 
The United Kingdom is Scotland's main market. The top five export sectors for Scotland's exports to the rest of the UK include: financial and insurance activities, wholesale and retail trade; repair of motor vehicles and motorcycles, utilities, professional, scientific and technical activities, manufacture of food products and beverages. ${ }^{38}$ In the event of Scottish independence, an international border would be introduced between an independent Scottish state and the continuing UK. This would create barriers to cross-border transactions and lead to increased costs for businesses and households operating or travelling across the border. These effects would cumulate across the economy and trigger a "border effect" - the barrier to flows of trade, labour and capital created by the weakening of economic integration. Different types of barriers (economic, legal, etc.) can cause that the development of trade will not happen in the same degree as expected. For instance, a factor hindering trade between Scotland and England would be the changes in customs policy with a wider use of protectionism instruments. The introduction of the border between Scotland and England would also not be favourable to bilateral exchange. Changing direction (shift) of trade is possible, but it requires time. However, it is not enough, it should involve the creation (increase) of trade. Various factors influence the development of foreign trade, including government policy (affects the direction of trade), exchange rate developments, demand for specific products/ services on the domestic market and on foreign markets, the economy's demand for products/ services needed for development individual sectors of the economy. This aspect should also be treated as a challenge for Scotland. In-depth analyses require not only potential effects in the sphere of trade in the conditions of Scotland's exit from the United Kingdom. They should also take into account the option of joining independent Scotland to the European Union in a situation where links with the markets of EU countries (except Great Britain) are currently relatively weak. In addition, the analyses should take into account the real possibilities of changing directions of trade and its increase (characteristic for a short period) and other long-term changes along with their potential effects on the Scottish economy.

Before the 2014 referendum, the then First Minister of Scotland, Alex Salmond, supported the monetary union with the rest of the United Kingdom: England, Wales and Northern Ireland, to be overseen by the Bank of England. According to the representatives of the Bank of England, in the event of Scotland gaining independence, Scotland will not be able to count on ending political union with the United Kingdom and remaining in the monetary union. If Scotland's monetary union was established with the rest of the United Kingdom, Scotland

38 According to the Export Statistics Scotland, in 2017, the top five largest sectors accounted for 59\% of the total exports to the rest of the UK 
would be required to comply with the decisions of the British Ministry of Finance and the Bank of England in fiscal (budgetary) policy, monetary policy, regulation of the banking sector. ${ }^{39}$ Additionally, for such a union to be functional, special cross-border agreements on tax and banking regulations would become necessary. Establishing Scotland's membership of the European Union, a possible monetary union and its own currency would only be a transitional stage preceding the adoption of the single euro currency. Scotland is not ready for this scenario yet. The own currency or possible adoption of the euro by Scotland should be based on strong foundations of the economy, including rational fiscal (budgetary) policy. The government will not be able to maintain a large budget deficit and public debt. The question arises: Will independent Scotland be able to finance free higher education, health care and planned increase in social spending? The results of experts' analyses from the Centre for Policy Studies indicate that in the optimistic variant, the fiscal net effect would be neutral, and in the pessimistic one, there would be a large shortage. Other parts of the United Kingdom can no longer afford to increase social spending. Maintaining social spending would be a considerable challenge for the independent government of Scotland, also in terms of the level of British debt, which after the possible secession of Scotland will have to be divided. The British government, in order to calm the financial markets, announced before the 2014 referendum that it would honour all debts, including those from Scotland, which means that independent Scotland will owe England approximately 23 billion British pounds. ${ }^{40}$ These were the estimates in 2014. This debt has been increasing since then.

Scotland is called the heart of Britain's energy industry. The deposits at the bottom of the North Sea (estimated to cover about 24 billion barrels of oil equivalent) do not belong to the United Kingdom, but to private enterprises that have found and exploited these deposits. The United Kingdom derives income from tax revenues on the activities of these enterprises. According to expert estimates from the Centre for Policy Studies, tax revenues from the operation of oil companies from the North Sea bottom, which in 2016 were estimated to reach 7.9 billion pounds, decreased to 500 million pounds. ${ }^{41}$ One of the main reasons is the drop in oil prices in the world. This means that the budget deficit in Scotland will remain stable in the coming years, definitely higher in the independent Scotland option than in the option of remaining Scotland in the UK. According to Scottish politi-

\footnotetext{
39 Carrell, S., Independent Scotland would face immediate £23bn debt, The Guardian, 8 April 2014 [http://www.theguardian.com/politics/2014/apr/08/independent-scotland-debt-thinktank] Accessed 05.02.2019

40 ibid.

41 Mahoney at al, op. cit, note 32, p. 3
} 
cians and economists, Scotland can handle these problems if tax revenues from oil extraction remain in Scotland. They are aware that oil and gas deposits are getting smaller, mining costs are rising and prices are falling. If the possible higher taxes on oil production raise, there is a risk that some enterprises may decide to withdraw from operation. The resources of energy are treated as one of the main pillars of Scotland's economic development after a possible exit from the United Kingdom. Before the 2014 independence referendum it was estimated that in the event of the victory of independence supporters, Scotland could take up as much as 84 per cent of UK oil resources. This issue in the case of secession in Scotland will have to be negotiated.

The renewable energy sector in Scotland has enormous potential, which has been pointed out, among others analysts from Bloomberg New Energy Finance before the 2014 referendum. ${ }^{42}$ At the beginning of the twenty-first century, the Scottish energy system was based mainly on hydroelectric, nuclear and coal power plants as well as the CCGT gas-fired power plant. In the new system, renewable energy sources have taken the priority place (RES). Their share in the Scottish energy mix (mainly due to wind energy) belongs to the highest in Europe now. The studies from already 2003 mentioned Scots' demand of energy was to be provided in 100 per cent by renewable sources of energy, but only the publication of "Scotland's Future. The Guide to an Independent Scotland "from November 2013 on the future of Scotland after gaining the independence, clearly underlined the development of renewable energy. This claim attracted investors who started to build wind farms on land and on the Scottish coast. The investors were also encouraged by the government subsidy system from London and Scotland's access to co-finance projects for the development of renewable energy from the EU structural funds (the UK's exit from the EU means a real possibility of losing these funds). A new energy strategy for Scotland published in January 2017 sustains the previous goal of developing renewable energy sources. ${ }^{43}$ Onshore wind energy is to develop without subsidising the energy produced by onshore wind farms. In return, the Scottish government plans its development by promoting the sale of energy from wind farms through long-term energy sales contracts, the so-called PPA (Power Purchase Agreements) concluded by the public and private sectors. If offshore wind energy has become competitive in relation to other energy production methods, specialists have no doubts that it is necessary to increase

42 Glickman, N., Clean energy investment at risk from Scottish referendum vote, Bloomberg New Energy Finance, 15 September 2014. [http://about.bnef.com/press-releases/clean-energy-investment-risk-scottish-referendum-vote/] Accessed 07.02.2019

43 Scottish Energy Strategy: The future of energy in Scotland, Scottish Government, Edinburgh, January 2017. [https://beta.gov.scot/publications/scottish-energy-strategy-future-energy-scotland/pages/5/] Accessed 09.02.2019 
its profitability. Greater commitment is needed to improve energy efficiency, expand energy storage capacity and increase the potential of so-called demand mechanism, ie voluntary reduction of consumption during periods of peak demand. The security of deliveries in emergency situations is now primarily provided by an interconnector linking the Scottish network with the English network. For several years, however, the government in London has been less and less enthusiastic about the costs of maintaining ready-made generating capacity in the event of insufficient electricity production in Scotland. The Scottish government convinces that it will not cause the drops of voltage or power outages. As part of the new strategy, the construction of interconnectors with Iceland and Norway is considered. For the Scottish Government, it is another step in the quest to become independent from England. According to the report published by specialists from the Frankfurt School - UNEP Collaborating Centre for Climate \& Sustainable Energy Finance and Bloomberg New Energy Finance in 2014, Great Britain took first place in Europe in terms of investments in the renewable energy sector. ${ }^{44}$ London government is unlikely to withdraw from financing new investments in Scottish wind farms. If it did, it would also be detrimental to its own interests. A large part of the British demand for renewable energy is satisfied thanks to Scottish wind farms. With the development of RES, Scotland is planning to remain a significant energy exporter. According to the data from 2016, approx. 24 per cent of electricity generated by wind farms is consumed in Scotland alone, and 76 per cent is exported (also to England) or does not enter the network at all. In order to increase the export potential, it is necessary to increase wind farm generation capacity, which is realistic considering the implemented and planned investments. The Scottish government has also set the aim of reducing greenhouse gas emissions by 66 per cent before 2032. The increase in the sales of electric cars should have an impact on stabilising the energy demand in the transport sector. ${ }^{45}$ The Scottish Government has also announced the support for innovation in clean energy technologies. The scientists from Scottish universities have also got involved in the cooperation in the research and development field supporting the development of innovation in the sector. Scotland expects that thanks to the involvement of foreign investors and EU structural funds (assuming Scotland's membership in the EU), it will be possible to implement the objectives of the new energy strategy in the long term, and renewable energy sources will become one of the pillars of independent Scotland's economic development.

The financial sector plays an important role in the economy of Scotland. Investors and consumers have felt the negative effects of the global financial crisis. In this

\footnotetext{
44 Global trends in renewable energy investment 2016, Frankfurt School - UNEP Collaborating Centre for Climate \& Sustainable Energy Finance \& Bloomberg New Energy Finance, Frankfurt, 2016, p. 23

45 Scottish Energy Strategy..., op. cit., note 37, p. 58
} 
context, before the 2014 referendum, the concerns about the future of the Scottish financial sector were voiced in the event of secession decisions. There is a real possibility of risk of assets relocation (after gaining the independence, the banks based in Scotland may withdraw from Scotland for greater security guaranteed by the Bank of England, and only possibly leaving local branches), withdrawal of savings deposits from banks, introduction of restrictions in the free movement of capital. The authors of the report "Scotland analysis: Macroeconomic and fiscal performance" point out this fact. ${ }^{46}$ Also, the partially nationalised banking groups of RBS (Royal Bank of Scotland) and LBG (Lloyds Banking Group) have announced that in the event of a possible exit of Scotland from the United Kingdom, they will relocate assets, and transfer their seats from Edinburgh to London. These banks were recapitalised in the years 2008-2009 during the crisis on the financial markets, they received multibillion aid from the British budget. The British Treasury is a shareholder of both banks. ${ }^{47}$ The independence of Scotland can affect the valuation of Scotland's credit rating, fiscal (budgetary) policy, monetary system, law and other elements that shape the environment in which the banks operate. Market participants function today in conditions of uncertainty, and are able to accept a certain level of it. In the short-term, the negative consequences for the financial system of Scotland would have an impact on the rate of economic growth and other macroeconomic indicators.

\section{SUMMARY}

Over the centuries, Scotland has made several attempts to become independent from Great Britain. They ended in failure for various reasons, although they have contributed to the increase of Scottish autonomy. Since the discovery of oil and gas deposits at the bottom of the North Sea and the growing importance of the Scottish National Party on the political scene and its supporters, the intensification of Scotland's efforts to separate from the United Kingdom can be seen. They have become particularly strong after the results of the EU referendum were announced. The basis for independence pursuits in Scotland is primarily the desire to become independent from the United Kingdom in the economic sphere. Scotland is determined to decide for itself about its own development as an independent state, and member-

46 Scotland analysis: Macroeconomic and fiscal performance, HM Government, London, September 2013, p. 23 [https://www.gov.uk/government/uploads/system/uploads/attachment_data/file/236579/scotland_analysis_macroeconomic_and_fiscal_performance.pdf] Accessed 12.02.2019

47 Trotman, A.; Roland, D.; Titcomb, J., RBS and Lloyds will leave Scotland if it votes for independence, The Telegraph, 11 September 112014

[http://www.telegraph.co.uk/finance/newsbysector/banksandfinance/11088643/RBS-and-Lloydswill-leave-Scotland-if-it-votes-for-independence.html] Accessed 13.02.2019 
ship in the European Union is treated as an important support for the implementation of the adopted concept of economic development based mainly on oil and gas and renewable energy sources. These efforts are a complex process in the present conditions. England is blocking the secession process of Scotland in order to maintain the unity of the United Kingdom. Assuming the achievement of the second independence referendum and its positive outcome for Scotland, bilateral negotiations and arrangements will be necessary regarding the conditions of secession: the economic, financial and institutional-legal exit of Scotland from the United Kingdom. The United Kingdom is a member of, among others UN, NATO, Council of Europe. Independent Scotland would have to negotiate and sign new agreements with many international organisations. ${ }^{48}$ Concerning Scotland's membership in the European Union, it does not seem to be enough to change treaties so that Scotland can remain a member of the Union. Scotland will need to apply as a new country for the admission to the European Union. In accordance with the procedure of accession of a new country to the Union, after starting the accession process, the European Commission will formulate opinions at various stages of this process (socalled avis) regarding the degree of fulfilling the so-called Copenhagen criteria, i.e. conditions for entry into the Union, the so-called screening, ie a review of the law, negotiations will begin in problematic areas until the final arrangements which will be recorded in the accession treaty. Then, the treaty will have to be ratified, only then will it apply. Scotland is a part of Great Britain, which joined the Union in 1973. Since then, it has been customising the so-called acquis communautaire, or the legal acquis of the European Union in these areas, which result from the supremacy of EU law; and on the other hand, are the responsibility of the autonomous government of Scotland. It can be therefore expected that the accession process will be easier than if the country that has no integration experience such as Scotland is trying to join the EU. Some EU countries will not be too favourable for the secession of Scotland from the United Kingdom. Spain is a good example; the country officially expressed its opposition to Scotland's independence fearing that it might provoke and encourage other regions in European countries, including Catalonia, to fight for the legitimacy of referendum processes aimed at secession. There is a danger that this country (perhaps also others) will block Scotland entering the EU at the stage of voting in the Council of the European Union (the accession of a new country to the EU requires unanimity of all EU member states) or ratification of the accession treaty. If Scotland is effectively blocked by England in the aspect of proclaiming an independence referendum, or if the referendum is negative and its result is negative, Scotland will probably strive to further autonomy increase, including the right to

48 Aikens, J., The Legal Consequences of Scottish Independence, Cambridge Journal of International and Comparative Law, Vol. 3, No. 1, 2014, pp. 162-172 
decide on such strategic issues as foreign policy, armed forces, and increasing the income from oil and gas exploration from the North Sea floor would be available to the Scots. There are different possible scenarios for the events development. To a large extent, they depend on the content of the withdrawal agreement (which should include i.a. an outline of the objectives for a future relationship between the UK and the EU) regarding the conditions of leaving the Union, as well as further directions, forms and principles of cooperation of the United Kingdom with this group. Scotland will have to conduct a national debate about its further status in the UK or elsewhere, including the relations with the European Union. The possible separation of Scotland from the United Kingdom generates many challenges in the economic sphere. Scotland is currently economically related mainly to the rest of the United Kingdom, including England. The concerns about adverse economic effects after the secession of Scotland are justified, especially in the short term. Scottish politicians are aware of the challenges. If they are undertaken, they are faced with the task of creating a pragmatic development strategy for independent Scotland in the long term. A strategy that will be accepted by the Scottish society, convinced that on the one hand the justified renunciation that will have to cope with during the creation of a new state and the 'rebuilding' of its structures and changes in socioeconomic policy; and on the other hand, that the choice they have made provides new opportunities and perspectives for them and their country.

\section{REFERENCES}

\section{BOOKS AND ARTICLES}

1. Aikens, J., The Legal Consequences of Scottish Independence, Cambridge Journal of International and Comparative Law, Vol. 3, No. 1, 2014, pp. 162-172

2. Bogdanor, V., Devolution in the United Kingdom, Oxford, 1999, p. 7

3. Colley, L., Britons: Forging the Nation, 1707-1837, New Haven: Yale, 1992, p. 11

4. Colomb, C.; Bakke, K.; Tomaney, J., Shaping the territory in Scotland, Catalonia and Flanders. Analysing contemporary debates on devolution and independence from a spatial planning and territorial cohesion lens, UCL European Institute, Working Paper, No. 5, 2014, pp. 1-12

5. Duerr, G., Scottish Secession: Prospects for Independence after Blair?, paper presented at the conference Britain after Blair, The Legacy and the Future, The Gleacher Center, University of Chicago Business School, Chicago, 29 August 2007

6. Emerson, M., Cameron's 'renegotiations' (or Russian roulette) with the EU. An interim assessment, CEPS - Centre for European Policy Studies Working Documents, No. 413, 2015, p. 1

7. Fraser of Allander Institute, Long-term Economic Implications of Brexit, October 2016

8. Global trends in renewable energy investment 2016, Frankfurt School - UNEP Collaborating Centre for Climate \& Sustainable Energy Finance \& Bloomberg New Energy Finance, Frankfurt, 2016, p. 23 
9. Hanham, H.J., Scottish Nationalism, London, 1969, p. 163

10. Ichijo, A., Scottish Nationalism and the Idea of Europe: Concepts of Europe and the Nation, New York, 2004, p. 33

11. Lynch, P., Scottish Independence, the Quebec Model of Secession and the Political Future of the Scottish National Party, Nationalism and Ethnic Politics, Vol. 11, No. 4, 2005, pp. 503-531

12. Mahoney, D.; Knox, T., Scotland: Could it become Greece without the sun?, Centre for Policy Studies, Economic Bulletin, No. 80, 2016, p. 4

13. Major, J., John Major: the Autobiography, New York, 1999

14. McCrone, D., Understanding the Nation: The Scottish Question, w: The Fate of the NationState, Montreal, 2004, p. 217

15. McInnes, R.; Ayres, S.; Hawkins, O., Scottish Independence Referendum 2014. Analysis of results, House of Commons, Research Paper No. 14/50, 2014, p. 22

16. Robbins, K., Britain and Europe: Devolution and Foreign Policy, International Affairs, Vol. 74, No. 1, 1998, pp. 105-118

17. Scotland's Place in Europe: People Jobs and Investment. Summary, Scottish Government, January 2018 , p. 3

18. Troitino, D.R., Margaret Thatcher and the EU, Proceedings for the Institute for European Studies, No. 6, 2009, pp. 124-150

\section{NATIONAL REGULATIONS, ACTS AND COURT DECISIONS}

1. Agreement between the United Kingdom Government and the Scottish Government on a referendum on independence of Scotland, Edinburgh, 15 October 2012

\section{WEBSITE REFERENCES}

1. Brexit and Scotland's future: First Minister statement, 24 April 2019. [https://www.gov.scot/ publications/first-minister-statement-brexit-scotlands-future/] Accessed 03.05.2019

2. Brexit: UK and EU agree delay to 31 October, BBC, 11 April 2019 [https://www.bbc.com/ news/uk-politics-47889404] Accessed 02.05.2019

3. Carrell, S., Independent Scotland would face immediate £23bn debt, The Guardian, 8 April 2014 [http://www.theguardian.com/politics/2014/apr/08/independent-scotland-debt-thinktank] Accessed 05.02.2019

4. Carrell, S., Sturgeon outlines new Scottish independence referendum plans, The Guardian, 24 April 2019 [https://www.theguardian.com/politics/2019/apr/24/sturgeon-outlines-newscottish-independence-referendum-plans] Accessed 03.05.2019

5. David Cameron's EU speech, 23 January 2013 [http://www.theguardian.com/politics/2013/ jan/23/david-cameron-eu-speech-referendum] Accessed 28.12.2018

6. Cramb, A., Nicola Sturgeon: Scottish referendum could be held next year, The Telegraph, 17 July 2016 [http://www.telegraph.co.uk/news/2016/07/17/sturgeon-scottish-referendumcould-be-held-next-year/] Accessed 23.01.2019

7. Erlanger, S.; Castle, S., David Cameron and Conservatives Get Majority in British Election, The New York Times, 8 May 2015 [http://www.nytimes.com/2015/05/09/world/europe/ 
david-cameron-and-conservatives-emerge-victorious-in-british-election.html] Accessed 06.01.2019

8. Glickman, N., Clean energy investment at risk from Scottish referendum vote, Bloomberg New Energy Finance, 15 September 2014 [http://about.bnef.com/press-releases/clean-energyinvestment-risk-scottish-referendum-vote/] Accessed 07.02.2019

9. Jamieson, A., Scotland Seeks Independence Again After U.K. 'Brexit' Vote, NBC News, 24 June 2016, [http://www.nbcnews.com/storyline/brexit-referendum/scotland-could-seekindependence-again-after-u-k-brexit-vote-n598166] Accessed 17.11.2018

10. Keating, M., Brexit Reflections - How could Scotland remain in the EU?, Centre on Constitutional Change, University of Edinburgh, Edinburgh, 8 July 2016 [http://www.centreonconstitutionalchange.ac.uk/blog/brexit-reflections-how-could-scotland-remain-eu] Accessed 21.01.2019

11. McAngus, C., Scottish independence back in play after Brexit shock - with a note of caution, The Conversation, 24 June 2016 [http://theconversation.com/scottish-independence-backin-play-after-brexit-shock-with-a-note-of-caution-61457] Accessed 05.12.2018

12. National Records of Scotland. 2016 [http://www.nrscotland.gov.uk/] Accessed 15.11.2018

13. PM Commons statement on the result of the EU referendum, 27 June 2016 [https://www.gov. uk/government/speeches/pm-commons-statement-on-the-result-of-the-eu-referendum27-june-2016] Accessed 25.01.2019

14. PM Scotland speech, 16 February 2012 [https://www.gov.uk/government/speeches/transcript-pm-scotland-speech] Accessed 01.02.2019

15. Rankin, J.; Carrell, S.; Oltermann, Ph., Nicola Sturgeon's plea to EU leaders meets with sympathy but little hope, The Guardian, 29 June 2016, [http://www.theguardian.com/politics/2016/jun/29/nicola-sturgeon-scotland-plea-eu-leaders-sympathy-little-hope] Accessed 08.01.2019

16. Scottish Energy Strategy: The future of energy in Scotland, Scottish Government, Edinburgh, January 2017, [https://beta.gov.scot/publications/scottish-energy-strategy-future-energyscotland/pages/5/] Accessed 09.02.2019

17. Scotland analysis: Macroeconomic and fiscal performance, HM Government, London, September 2013, p. 23, [https:/www.gov.uk/government/uploads/system/uploads/attachment_data/file/236579/scotland_analysis_macroeconomic_and_fiscal_performance.pdf] Accessed 12.02.2019

18. Scotland's Future. The Guide to an Independent Scotland, Scottish Government, Edinburgh, November 2013 [http://www.gov.scot/resource/0043/00439021.pdf] Accessed 17.12.2018

19. The Queen's address to the Scottish Parliament, 2 July 2016 [https://www.royal.uk/queens-address-scottish-parliament-2nd-july-2016] Accessed 30.01.2019

20. Trotman, A.; Roland, D.; Titcomb, J., RBS and Lloyds will leave Scotland if it votes for independence, The Telegraph, 11 September 2014 [http://www.telegraph.co.uk/finance/newsbysector/banksandfinance/11088643/RBS-and-Lloyds-will-leave-Scotland-if-it-votes-for-independence.html] Accessed 13.02.2019 